\title{
Liraglutide and Insulin Have Contrary Effects on Adipogenesis of Human Adipose-Derived Stem Cells via Wnt Pathway
}

This article was published in the following Dove Press journal: Diabetes, Metabolic Syndrome and Obesity: Targets and Therapy

\author{
Hong Liu ${ }^{1,2}$ \\ Yan-li Zhan (iD) 2,3 \\ Guo-jing Luo 2,4 \\ Ling-ling Zou ${ }^{2,5}$ \\ Yun $\mathrm{Li}$ iD $^{2}$ \\ Hong-yun Lu (iD) 2,4 \\ 'Department of Nutrition, The Third \\ Xiangya Hospital, Central South \\ University, Changsha, Hunan, People's \\ Republic of China; ${ }^{2}$ Department of \\ Endocrinology \& Metabolism, The Fifth \\ Affiliated Hospital of Sun Yat-Sen \\ University, Zhuhai, Guangdong, People's \\ Republic of China; ${ }^{3}$ Department of \\ Rheumatology, Jiaozuo People's Hospital, \\ Jiaozuo, Henan, People's Republic of \\ China; ${ }^{4}$ Department of Endocrinology \& \\ Metabolism, Zhuhai Hospital Affiliated \\ with Jinan University, Zhuhai People's \\ Hospital, Zhuhai, Guangdong, People's \\ Republic of China; ${ }^{5}$ Department of \\ Endocrinology, The Second People's \\ Hospital of Hefei, Anhui, People's \\ Republic of China
}

Background: Glucagon-like peptide-1 (GLP-1) has been reported to have beneficial impacts on improving human's metabolism and ameliorating insulin resistance. While insulin is another important and conventional drug in diabetes treatment, but it has an adverse effect on weight gain.

Purpose: To make sure whether GLP-1 and insulin play different roles in human adiposederived stem cells (hADSCs).

Methods: We examined the in vitro roles and molecular mechanisms of liraglutide, a GLP-1 analogue, and human insulin on hADSCs isolated from subcutaneous adipose tissue. Different concentrations $(0,0.1,1,10,100 \mathrm{nM})$ of liraglutide and insulin were added to proliferation and differentiation medium of hADSCs, respectively.

Results: Liraglutide inhibits while insulin promotes the proliferation and differentiation at the concentration of $100 \mathrm{nM}$. Moreover, the levels of GSK-3 increase during differentiation and liraglutide could down-regulate it when compared with insulin. We also find that the activation of phosphorylated GSK-3 $\alpha$ and GSK-3 $\beta$ is involved in the differentiation roles. And classical and non-classical Wnt pathways all play roles in the differentiation, which are characterized with the up/down-regulation of the expression of adipogenesis genes such as PPAR- $\gamma$ and CEBP- $\alpha$.

Conclusion: Liraglutide and insulin have contrary effects on the proliferation and adipogenesis via Wnt pathway in primary cultured ADSCs. Those effects could partly explain the different roles of GLP-1 and insulin on weight gain and insulin resistance.

Keywords: liraglutide, insulin, human adipose-derived stem cells, obesity, Wnt signaling pathway

\section{Introduction}

The global epidemic of obesity and other related metabolic complications has reignited interest in adipose tissue and its role in the development of metabolic diseases. ${ }^{1,2}$ White adipose tissue (WAT), consisting of visceral adipose tissue (VAT) and subcutaneous adipose tissue (SAT), plays an important role in lipid and glucose metabolism. ${ }^{3}$ In fact, WAT dysfunction is strongly implicated in the development of obesity-related diseases. SAT is the body's largest repository of adipose tissue and the biggest place to store excess calories and release essential fat as needed. ${ }^{1}$ SAT expansion is best done by recruiting new cells, not just merely expanding available fat cells. High caloric intake and/or reduced energy expenditure lead to positive energy balance. This usually leads to an increase in adipose tissue through two different mechanisms. ${ }^{4}$ Firstly, excess energy is stored in existing fat cells in the form of additional triglycerides, causing
Correspondence: Hong-yun Lu Department of Endocrinology \& Metabolism, The Fifth Affiliated Hospital of Sun Yat-Sen University, No. 52 Meihua East Road, Zhuhai, Guangdong 519000 , People's Republic of China

Tel +86 756-252 874l

Fax +867562528300

Email luhongy@mail.sysu.edu.cn 
those cells to grow larger, which is called hypertrophy. Secondly, if the number of adipocytes is insufficient to store more and more triglycerides, the adipogenesis of the mesenchymal precursor cells produces new adipocytes, a process known as hyperplasia. ${ }^{5}$ Hence, improving adipose tissue remodeling by breaking down triglycerides and inhibiting adipogenesis of mesenchymal precursor cells may have therapeutical potential against obesity. ${ }^{5}$

Insulin is a common therapy choice for type 1 diabetes and many people with type 2 diabetes, but insulin therapy increases the risk of weight gain. ${ }^{6,7}$ GLP-1 exerts various biological effects through the GLP-1 receptor (GLP-1R) and is the product secreted by intestinal $\mathrm{L}$ cells after nutrient intake. In addition to the well-known beneficial effects of treating type 2 diabetes, GLP-1 has also been shown to reduce weight gain, delay gastric emptying and increase satiety. ${ }^{8-10}$ Whether the opposite effect on weight is due to different effects on adipogenesis and lipolysis remains unclear.

Recent studies indicated that Wnt signaling had a unique role in controlling adipogenesis compared to the development into other mesenchymal lineages. ${ }^{11}$ In addition, the canonical Wnt pathway has been shown to be highly active in mesenchymal stem cells (MSCs) that regulate cell fate of anti-adipogenesis and pro-osteogenic activities, with GSK-3 $\beta$ protein exerts an important role. ${ }^{12}$ Conversely, endogenous inhibitors of Wnt signaling were found to promote adipocyte production, suggesting that these bioactive peptides play an important role in adipogenesis. Our previous research showed that Wnt signaling antagonist Dickkopf-1 promotes the differentiation of primary cultured human preadipocytes and the secretion of adipocytokines through classical Wnt signaling pathway. ${ }^{13}$

Previous studies about the roles of GLP-1 and its analogues or insulin on adipose cells were mostly conducted in animal cells, few studies on human adipose cells have been reported. However, there are significant genetic differences and different metabolic pathways between humans and rodents. Therefore, the purpose of this study was to compare the effects of GLP-1 analogue (liraglutide) and insulin on proliferation, differentiation and lipid metabolism of human adipose-derived stem cells (hADSCs) isolated from SAT, and the underlying molecular mechanisms.

\section{Materials and Methods}

\section{Subjects and Ethics Statement}

SAT samples were collected from 18 non-diabetic and non-obese patients $[9$ males and 9 females, aged 30 50 years, with body mass index (BMI)] of $18.5-23.9 \mathrm{~kg} / \mathrm{m}^{2}$ who underwent elective abdominal surgery in the Fifth Affiliated Hospital of Sun Yat-sen University during November 2015 to March 2017. The experimental plan and informed consent document were approved by the local research ethics committee of the Sun Yat-sen University. All patients provided informed consent, and that this study was conducted in accordance with the Declaration of Helsinki.

\section{Reagents}

Collagenase type I (Sigma, USA); erythrocyte lysis buffer (Biotime, China); Dulbecco's modified Eagle's medium (DMEM); DMEM/F12 (1:1) and penicillin/streptomycin solution were obtained from Hyclone, USA; transferrin (Biosharp, China); triiodothyronine (Sigma, USA); dexamethasone (Roche, Switzerland); 3-isobutyl-1-methylxanthine (IBMX) (Sigma, USA); fetal bovine serum (FBS) (Sigma, USA); MTT assay (Sigma, USA); liraglutide and human insulin (Novo Nordisk, Denmark); LiCl (Amresco, USA); SB-216763 (Selleck, USA); Antibodies against PPAR- $\gamma$, C/EBP- $\alpha$ and Pref-1 (Genetex, USA); Antibodies against $\beta$-catenin and GAPDH (Santa Cruz, USA); Antibodies against GSK- $3 \alpha$, GSK-3 $\beta$, phosphorylated GSK$3 \alpha$ and phosphorylated GSK-3 $\beta$ (Abclonal, USA).

\section{Isolation, Culture and Differentiation of hADSCs from Subcutaneous Adipose}

\section{Tissue}

As previously mentioned, hADSCs were isolated and cultured from SAT. ${ }^{14,15}$ In short, tissue samples from each donor (15-20g) were separated from the visible connective tissue, finely cut into $1.0 \mathrm{~mm}^{2}$ blocks, and digested with collagenase type I. The digested tissue was filtered and centrifuged in stages and then incubated in the erythrocyte lysis buffer. hADSCs were inoculated in growth medium at a density of $5 \times 10^{6}$ cells $/ \mathrm{cm}^{2}$ in growth medium, which consisted DMEM supplemented with $10 \% \mathrm{FBS}$ and $1 \%$ penicillin/streptomycin solution $(\mathrm{P} / \mathrm{S}) .{ }^{14,15}$ In order to induce differentiation, the growth medium was replaced to serum-free differentiation medium after cells fusion of $90 \sim 96 \%$ confluence. The differentiation medium was made by DMEM/F12 (1:1), $1 \mu \mathrm{mol} / \mathrm{L}$ dexamethasone, $1 \mu \mathrm{mol} / \mathrm{L}$ insulin, $10 \mu \mathrm{g} / \mathrm{mL}$ transferrin, and $0.1 \mathrm{mmol} / \mathrm{L}$ IBMX. The cells were cultured in the differentiation medium for 3 days and transferred to the maintenance medium from day 4 . The maintenance medium was the same with 
differentiation medium except IBMX were omitted. The medium was changed every 3 days. ${ }^{14,15}$

\section{Treatment of Liraglutide and Insulin on hADSCs Proliferation}

To determine whether liraglutide and insulin treatments affect hADSCs viability, an MTT assay was used according to the manufacturer's instructions and previously described. ${ }^{13}$ hADSCs were seeded in triplicate with a density of $5 \times 10^{4}$ cells/well in $100 \mu \mathrm{L}$ of growth medium in 96-well plates. After cells reached $50 \sim 60 \%$ confluence, they were treated with different concentrations of liraglutide $(0,0.1,1,10$ and $100 \mathrm{nM})$ and insulin $(0,0.1,1,10$ and $100 \mathrm{nM}$ ) for 24,48 and 72 hours, respectively.

\section{Treatment of Liraglutide and Insulin on hADSCs Differentiation}

hADSCs were inoculated in growth medium at a density of $2 \times 10^{6}$ cells/well, and repeated in 6-well plates for three times. After cells reached 90 95\% confluence, they were transferred to differentiation medium including liraglutide $(100 \mathrm{nM})$ or insulin $(100 \mathrm{nM})$, respectively. The morphological pictures about the number of lipid droplets were analyzed at the end of day 21 using Image-Pro Plus 5.02. At least 8 different microscopic fields were used to determine the number of fat cells in each well. RNA of treated hADSCs was extracted at days $0,7,9,14,21$ and total protein was extracted at days $0,3,9,15$ and 21 after inducing adipogenesis differentiation. Supernatant and cell lysates were collected at days $0,3,9,15$ and 21, respectively, and then stored in the refrigerator at $-80^{\circ}$ for later determination.

\section{Treatment of GSK-3 Inhibitors on Wnt Signaling During Adipogenesis Differentiation}

hADSCs were inoculated at a density of $2 \times 10^{6}$ cells/well in a 6-well plate for three times. After cells reached 90 95\% confluence, they were transferred to differentiation medium including GSK-3 small molecular inhibitor SB-216763 $(20 \mu \mathrm{M})$ or chemical inhibitor $\mathrm{LiCl}(20 \mathrm{mM})$ for 7, 14 and 21 days, respectively. Total RNA and protein were extracted from each group, respectively, and changes in the expression levels of PPAR- $\gamma, \mathrm{C} / \mathrm{EBP}-\alpha, \mathrm{GSK}-3 \alpha$, GSK-3 $\beta$, $\beta$-catenin, Wnt3a and Wnt5a were detected, as well as oil red $\mathrm{O}$ staining was used to evaluate the degree of lipid differentiation.

\section{Quantitative RT-PCR}

mRNA expression levels of adipogenic differentiation related genes at $0,7,14$ and 21 days were detected by realtime quantitative PCR (qRT-PCR). Total RNA was isolated from the cells using TRIZOL ${ }^{\circledR}$ Reagent, 500ng total RNA was used for cDNA synthesis using cDNA reversetranscription kit. Gene-specific primers were designed using Primer Express software. The primer sequences were shown in Table 1. Quantitative real-time PCR was performed by using the Takara kit $\left(\mathrm{SYBR}^{\circledR}\right.$ Premix Ex TaqTM II, item no. RR820A) according to manufacturer instructions. GAPDH was selected as the internal reference gene, and the PCR reaction was carried out using the ABI 7500HT Fast Real-Time PCR system (Applied Biosystems, Foster City, CA). Relative quantification of mRNA levels was plotted as the fold change using the $2^{-}$ $\Delta \Delta \mathrm{Ct}$ method, generally compared with those cultured in the control medium. Analyses were performed in duplicates, and all experiments were repeated at least three times.

\section{Western Blotting}

Cell proteins were extracted using the total protein extraction kit (Sangon, Shanghai, China, item no. BSP003), and $5 \mu \mathrm{L}$ phosphatase inhibitor, $1 \mu \mathrm{L}$ protease inhibitor, and $10 \mu \mathrm{L}$ phenylmethanesulfonyl fluoride (PMSF) were mixed in per $1 \mathrm{~mL}$ precooled lysis buffer. Protein concentration was determined using the BCA assay kit (Sangon, Shanghai, China, item no. SK3021). And Western blot was conducted as previously described. ${ }^{16}$

\section{Enzyme-Linked Immunosorbent Assay}

Supernatants stored in the refrigerator at $-80^{\circ}$ were collected, and enzyme-linked immunosorbent assay (ELISA) techniques were used to analyze the concentrations of GSK-3 $\beta$ (Enzo Life Sciences, USA) according to the manufacturer's instructions and previously described. ${ }^{13}$

\section{Glycerol and TG Assays}

Supernatant medium was used to determine glycerol production, cytosolic protein extract and triglyceride, using a commercially available colorimetric kits (Enzo Life Sciences, USA). To detect TG in adipocytes, oil red $\mathrm{O}$ staining was performed as previously described. ${ }^{16}$ Select culture dishes and then fixed them with $10 \%$ formalin (Sigma-Aldrich) for at least $1 \mathrm{~h}$. For quantitative analysis of TG, the standard chloroform/methanol (2:1) method was 
Table I Primer Sequences Used for Quantitative Real-Time PCR

\begin{tabular}{|l|l|l|l|}
\hline Target Gene & Accession No & Primer Sequence & Product Size (bp) \\
\hline PPAR- $\gamma$ & NM_015869 & $\begin{array}{l}\text { F-CCTATTGACCCAGAAAGCGATT } \\
\text { R-CATTACGGAGAGATCCACGGA }\end{array}$ & 135 \\
\hline CIEBP- $\alpha$ & NM_004364.3 & $\begin{array}{l}\text { F-CTTGGTGCGTCTAAGATGAGGG } \\
\text { R-CATTGGAGCGGTGAGTTTGC }\end{array}$ & 143 \\
\hline Wnt3a & NM_033131.2 & $\begin{array}{l}\text { F-TCCAGCTACAGGAGAGATAGAA } \\
\text { R-CTTCCTACCTTTCCCTTAAGG }\end{array}$ & 86 \\
\hline Wnt5a & NM_003392 & $\begin{array}{l}\text { F-CTTCCTACCTTTCCCTTAAGG } \\
\text { R-AGTGGCACAGTTTCTTCTGTC }\end{array}$ & 119 \\
\hline GSK-3 $\alpha$ & NM_019884 & $\begin{array}{l}\text { F-GGGAGCCCAATGTCTCCTACA } \\
\text { R-CACAGCCAGCTGACCAAACA }\end{array}$ & 108 \\
\hline GSK-3 $\beta$ & NM_002093 & $\begin{array}{l}\text { F-GGCAGCAAGGTGACAACAG } \\
\text { R-TGCAATACTTTCTTGATGGCG }\end{array}$ & 114 \\
\hline -catenin & NM_020248.2 & F-GCATCAAGGGAGACACCA \\
R-TGACCTAACTAAAGCACCAGA & F-GCTCTCTGCTCCTCCTGTTC \\
R-ACGACCAAATCCGTTGACTC & 208 \\
\hline
\end{tabular}

used to extract TG from the whole cell lysate. As previously mentioned, TG was enzymatically quantified using a serum triglyceride assay kit. ${ }^{16}$ Result of TG (mg)/protein (mg) was normalized according to the protein concentration of the whole cell lysate.

\section{Statistical Analysis}

Each experiment was performed at least 3 times, using cells from independent subjects for the specified replication. The values were expressed as means \pm standard deviation (SD), the Student's $t$-test and one-way analysis of variance with SPSS 25.0 software. $P$-value $<0.05$ was considered statistically significant.

\section{Results}

\section{Effects of GLP-I Analogue and Insulin on hADSCs Proliferation}

We successfully established the primary culture model of human ADSCs and amplified it in vitro, providing a cytological research platform for the next step. Human ADSCs were fusiform and fibroblast-like cells that can be induced to differentiate into adipocytes in vitro (Figure 1A). MTT method was used to evaluate the effects of liraglutide and insulin on cell viability in vitro. We treated hADSCs with liraglutide $(0-100 \mathrm{nM})$ or insulin $(0-100 \mathrm{nM})$ for 24,48 and 72 hours, respectively, to observe cell growth. hADSCs growth was significantly inhibited by liraglutide and promoted by insulin on $100 \mathrm{nM}$ at 72 hours $(p<0.01)$ (Figure 1B). There was a trend of dose response in the range of $0-100 \mathrm{nM}$, but there was no statistical difference. In addition, 100nM liraglutide inhibited hADSCs proliferation significantly, while insulin promoted hADSCs proliferation. Therefore, in the following experiments, we used liraglutide and insulin treated with $100 \mathrm{nM}$.

\section{Effects of GLP-I Analogue and Insulin on Adipocyte-Specific Markers During hADSCs Differentiation}

We performed morphological pictures to compare the effect of liraglutide and insulin on lipid droplet accumulation. Differentiation of hADSCs was induced for 21 days with dose of liraglutide or insulin on 100nM. Oil red O staining results revealed that the lipid droplet number decreased in culture treated with liraglutide while increased significantly in culture treated with insulin, as compared with control (Figure 2A).

To determine the effect of liraglutide and insulin on expression of genes regulating differentiation of hADSCs, the qRTPCR were utilized, and three groups were used, including control, insulin and liraglutide group. The main measuring 


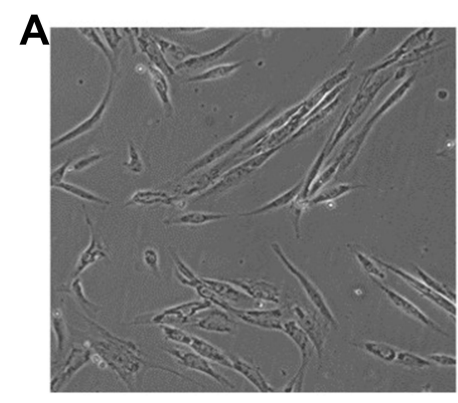

The $3^{\text {rd }}$ day of passage 1

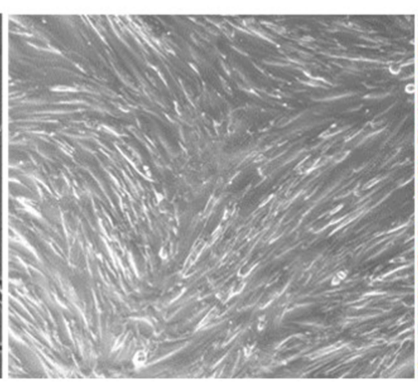

The $5^{\text {th }}$ day of passage 3

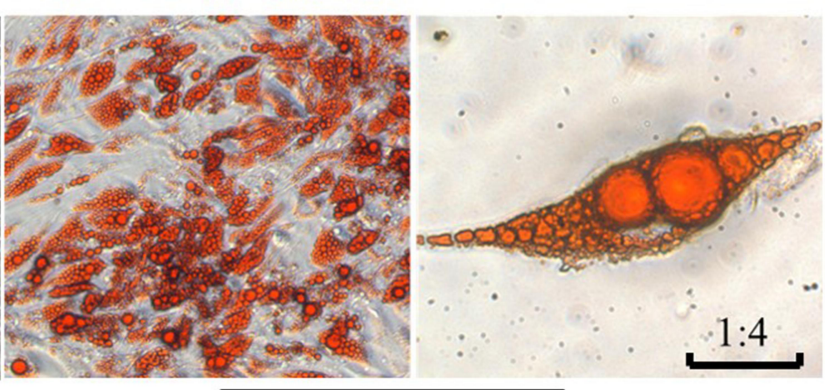

Oil red $O$ staining on the $21^{\text {st }}$ day $(100 \times, 400 \times)$

B

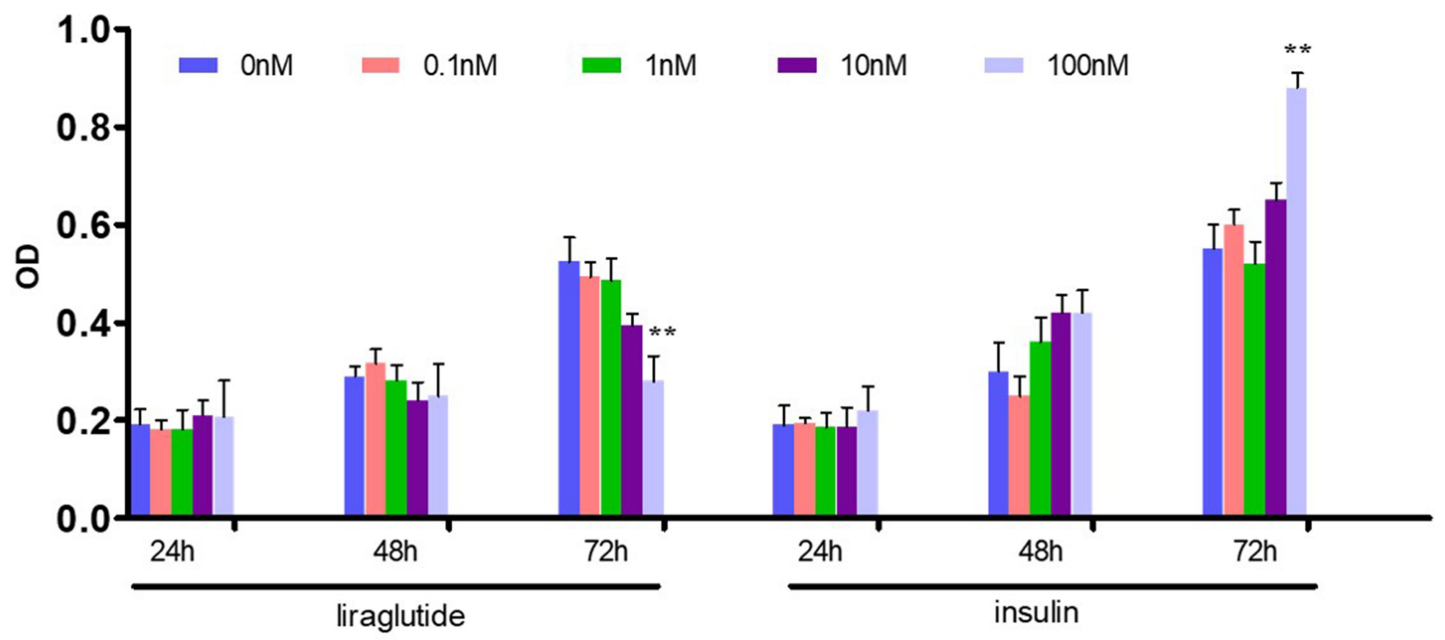

Figure I Primary culture of human adipose-derived stem cells (hADSCs) and the effects of liraglutide and insulin on hADSCs proliferation. (A) Culture of hADSCs and oil red $O$ staining. (B) MTT assay $(* * p<0.01)$.

indexes were $P P A R-\gamma$ and $C / E B P-\alpha$. The results revealed that both $P P A R-\gamma$ and $C E B P-\alpha$ showed an upward trend during normal adipogenesis differentiation (Figure $2 \mathrm{~B})(p<0.01)$. On the 7th day of differentiation, the relative mRNA levels of PPAR- $\gamma$ in insulin and liraglutide groups were 2.5, 1.6 times higher, and the $C E B P-\alpha$ were 2.1, 1.2 times higher than that in control group (Figure $2 \mathrm{C})(p<0.05)$. On the 14th day, the relative mRNA levels of PPAR- $\gamma$ in insulin group was 2.8 times higher, and the $C E B P-\alpha$ were 1.8 and 1.6 times higher than that in control group $(p<0.05)$ (Figure 2D). On the 21 st day, the PPAR- $\gamma$ and $C E B P-\alpha$ in GLP-1 group were 0.3 and 0.6 times $(p<0.05)$, respectively (Figure $2 \mathrm{E}$ ). After intervention of different concentrations of insulin $(0,0.1,1,10$, $100 \mathrm{nM}$ ), the protein expression of PPAR- $\gamma$ and $C / E B P-\alpha$ had no obvious change, and the expression of pref-1, which was the marker of preadipocyte, decreased gradually on the 21 st day $(p<0.05)$ (Figure 2F). While the protein levels of PPAR- $\gamma$ and C/EBP- $\alpha$ increased with the intervention of GLP1 over time $(p<0.05)$, and the expression of pref-1 also increased gradually $(p<0.01)$ (Figure $2 \mathrm{G})$.

\section{Effect of GLP-I Analogue and Insulin on GSK-3 $\beta$ During Adipogenesis \\ Differentiation}

In our experiments, GSK-3 $\beta$ ELISA kit was used to detect the changes in the expression level of total GSK-3 $\beta$ in the process of hADSCs adipogenesis differentiation, and it was found that the expression level of GSK-3 $\beta$ increased significantly with the process of adipogenesis differentiation $(p<0.01)$. The concentration of GSK$3 \beta$ before differentiation (D0) was $500 \mathrm{pg} / \mathrm{mL}$, which peaked on day $9(4676 \mathrm{pg} / \mathrm{mL})$ with the progress of differentiation, and showed a decreasing trend on day 15 , and continued to decrease to $2450 \mathrm{pg} /$ $\mathrm{mL}$ on day 21, but still significantly higher than D0 (Figure 3A).

Consistent with ELISA results, qRT-PCR results indicated that the relative mRNA levels of $G S K-3 \alpha$ and $G S K-3 \beta$ were significantly increased compared to pre-differentiation $(p<0.01$ for both groups, Figure 3B). On the 7th day, the relative mRNA levels of $G S K-3 \alpha$ and $G S K-3 \beta$ increased to 6.4 and 8.2 times of the original level, peaked on the 14th day (9.6 and 9.3 times, respectively), and decreased to 7.1 and 8.6 times on the 21 st day, respectively (both $p<0.01$ ). 


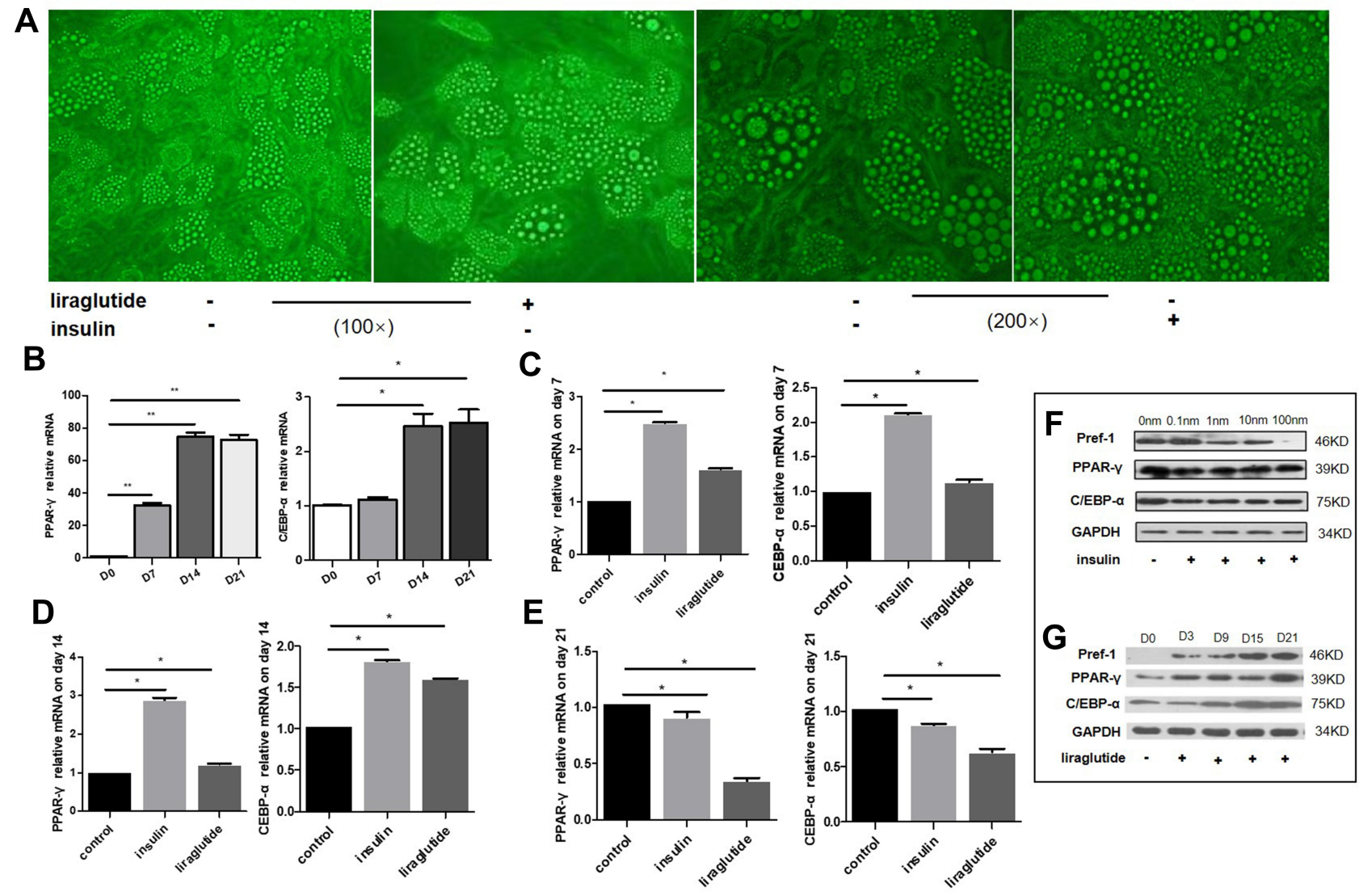

Figure 2 Effects of GLP-I analogue and insulin on adipogenesis differentiation of hADSCs. (A) The morphological pictures comparing the effects of liraglutide and insulin on lipid droplet accumulation. (B) Trends of PPAR- $\gamma$ and CEBP- $\alpha$ mRNA levels during normal adipogenesis differentiation. (C-E) Trends of PPAR- $\gamma$ and CEBP- $\alpha$ mRNA levels during adipogenesis differentiation after intervention by insulin and liraglutide. (C) On 7th day; (D) on I4th day; (E) on 2 I st day. (F and G) Protein levels of Pref-I, PPAR- $\gamma$ and CEBP- $\alpha$ during adipogenesis differentiation after intervention by insulin and liraglutide $\left({ }^{*} \mathrm{p}<0.05,{ }^{* *} \mathrm{p}<0.0 \mathrm{I}\right)$. (F) Intervention of different concentrations of insulin on the 21 th day. (G) Intervention of liraglutide at $100 \mathrm{nM}$ for 3, 9, 15 and 21 days.

After intervening with insulin and liraglutide for 9 days, the mRNA levels of $G S K-3 \alpha$ and $G S K-3 \beta$ in liraglutide groups down-regulated $0.44(p<0.05)$ and 0.22 times $(p<0.05)$, respectively, than insulin groups (Figure 3C). On the 21st day, GSK$3 \alpha$ and $G S K-3 \beta$ mRNA levels in liraglutide groups were 0.43 $(p<0.05)$ and 0.07 times $(p<0.05)$, respectively, as compared with insulin groups (Figure 3D). At the protein level, GSK-3 $\alpha$ and GSK-3 $\beta$ did not change significantly in insulin and GLP-1 groups, but phosphorylated GSK-3 $\beta$ in liraglutide group was up-regulated than insulin group on the 21st day during the adipogenesis differentiation (Figure $3 \mathrm{E}$ and $\mathrm{F}$ ).

\section{Effects of GSK-3 on Adipogenesis Differentiation}

To further confirm the effect of GSK-3 on adipogenesis differentiation, the two GSK-3 inhibitors lithium chloride ( $\mathrm{LiCl})$ and SB-216763 were added into the differentiation medium, respectively. And oil red $\mathrm{O}$ staining and adipogenesis-specific genes were measured after using GSK-3 inhibitors. Adipogenesis differentiation was evaluated by measuring OD value of oil red O eluted by isopropyl alcohol. At the end of 21 days of differentiation, both groups of GSK-3 inhibitors $\mathrm{LiCl}$ and SB216763 inhibited differentiation (Figure $4 \mathrm{~A}$ and $\mathrm{B}, p<0.05)$. However, there was no significant difference between GSK-3 inhibitors and control group on the 7th day and 14th day of differentiation (Figure 4B). PPAR- $\gamma$ and CEBP- $\alpha$ were significantly increased during normal adipogenesis differentiation (Figure 4B). After the addition of GSK-3 inhibitors, the relative mRNA levels of $P P A R-\gamma$ and $C / E B P-\alpha$ were significantly decreased. The lowest point was reached on the 14th day, the relative expression of PPAR- $\gamma$ mRNA in the two groups was 0.28 and 0.34 times of that in the control group $(p<0.01)$, and the relative expression of $C / E B P-\alpha$ mRNA was reduced to 0.15 and 0.40 times of that in the control group $(p<0.01$, $p<0.05$ ) (Figure 4C). 

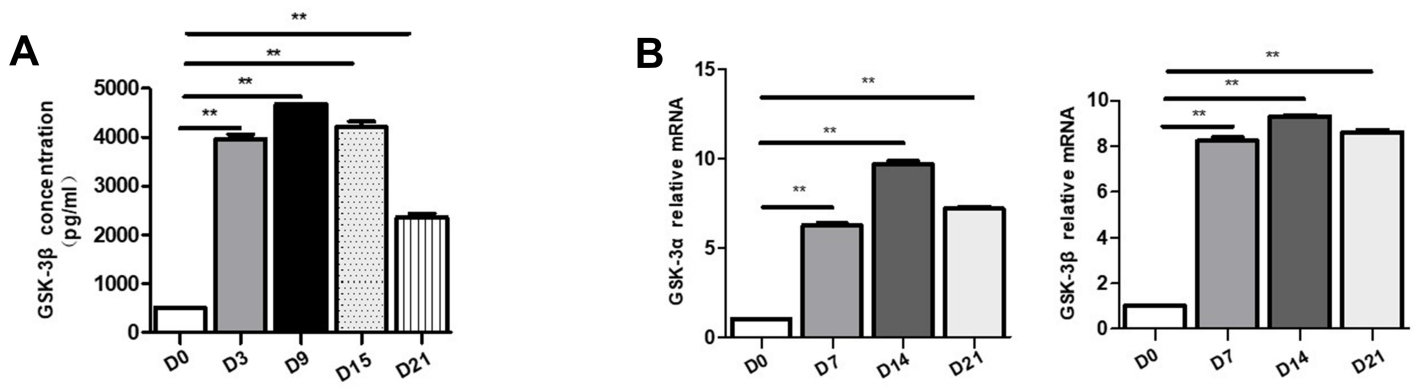

C
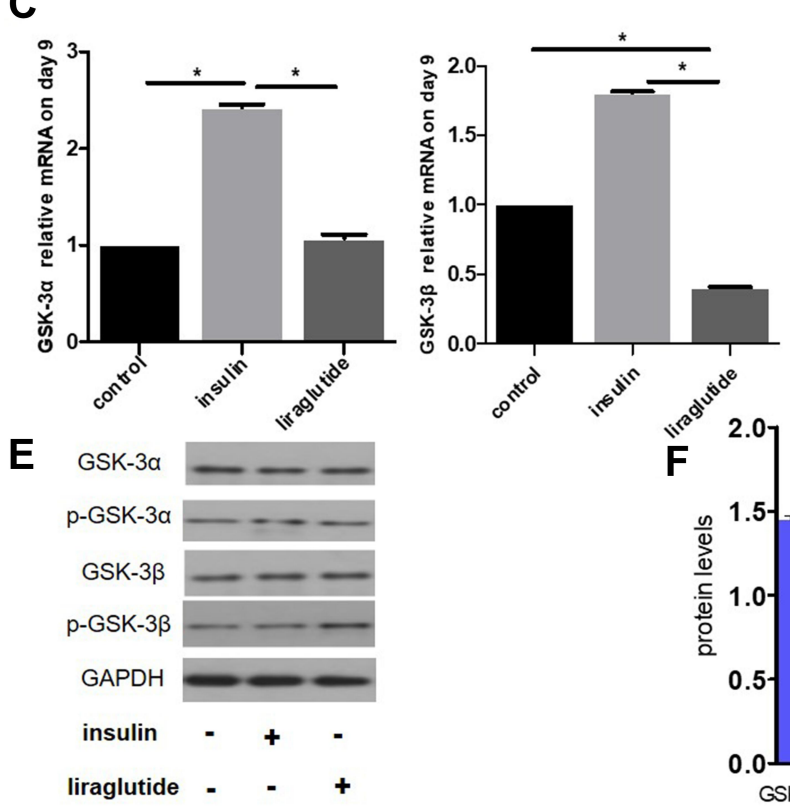

\section{D}
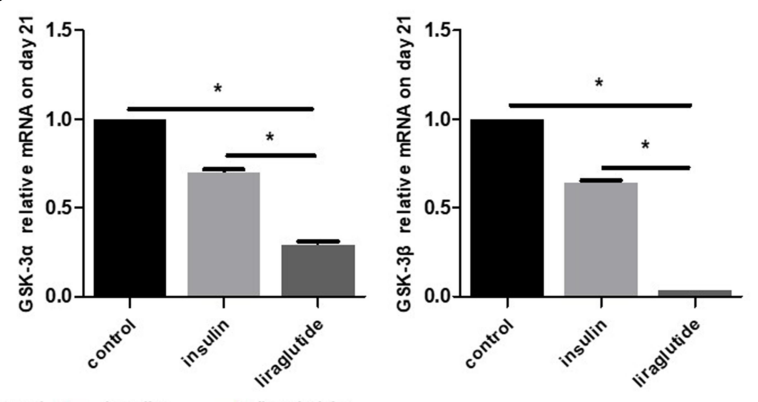

- control insulin liraglutide
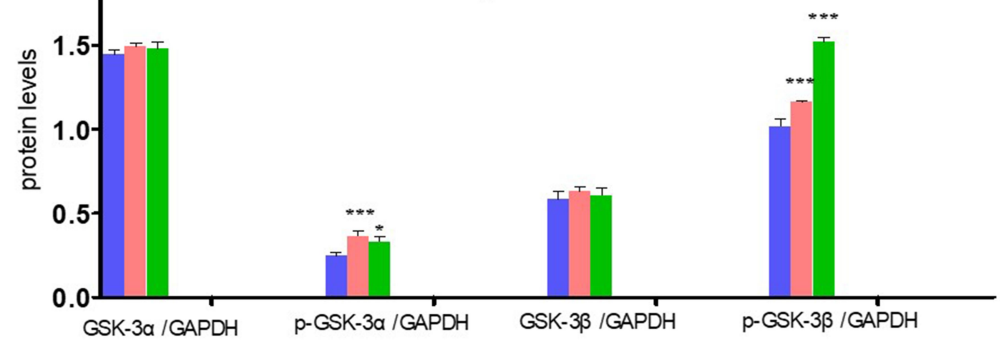

Figure 3 Effects of GLP-I analogue and insulin on GSK-3 during adipogenesis differentiation. (A) Changes of GSK-3 $\beta$ concentrations during adipogenesis differentiation of hADSCs on the 3rd, 9th, I5th and 21 st days measured by ELISA. (B) Changes of GSK-3 $\alpha$ and GSK-3 $\beta$ mRNA levels during adipogenesis differentiation of hADSCs on the 7th, 14th and 2 Ist days. (C and D) Changes of GSK-3 $\alpha$ and GSK-3 $\beta$ mRNA levels after intervening with insulin and liraglutide for 9 and 21 days. (C) The 9th day. (D) The 2 Ist day. (E and F) Changes of GSK-3 $\alpha$, GSK-3 $\beta$ and phosphorylated GSK-3 $\alpha$, GSK-3 $\beta$ protein levels after intervening with insulin and GLP-I for 21 days. (E) Protein Western blotting strip. (F) Quantify the protein levels with image J software $\left(* \mathrm{p}<0.05,{ }^{* *} \mathrm{p}<0.0 \mathrm{I},{ }^{* * *} \mathrm{p}<0.00 \mathrm{I}\right)$.

\section{Effects of GSK-3 on Wnt Signaling During Adipogenesis Differentiation}

To further clarify the role of GSK-3 in Wnt signaling pathway, we used GSK-3 inhibitors to intervene the adipogenesis differentiation and detect the changes of mRNA levels of Wnt $3 a$ and $\beta$-catenin, which belong to the classical Wnt signaling pathway, as well as the changes of $W n t 5 a$, which belong to the nonclassical signaling pathway. During normal adipogenesis differentiation, the mRNA levels of $W n t 3 a$ decreased to 0.79 , $0.40(p<0.05)$ and 0.76 times on the 7th, 14th and 21 st days of differentiation, respectively (Figure 5A). After adding GSK-3 inhibitors, the mRNA levels of Wnt $3 a$ showed no significant change in $\mathrm{LiCl}$ group, while decreased significantly to 0.49 times in SB-216763 group $(p<0.05)$ on the 7 th day. On the 14th day, the $W n t 3 a$ levels increased to 2.07 times in $\mathrm{LiCl}$ group $(p<0.05)$, while had no significant change in SB-216763 group. On the 21st day, the Wnt $3 a$ levels decreased to 0.74 times in $\mathrm{LiCl}$ group, while increased to 4.25 times $(p<0.01)$ in SB-216763 group (Figure 5A).

On the 7th, 14th and 21st day of differentiation, $\mathrm{LiCl}$ group significantly down-regulated the relative mRNA levels of $\beta$-catenin (both $p<0.05$ ), while SB-216763 group significantly up-regulated its expression (both $p<0.01$ ) (Figure 5C). However, in terms of protein levels, both $\mathrm{LiCl}$ and SB-216763 group up-regulated the protein levels of $\beta$-catenin (Figure 5E).

During normal adipogenesis differentiation, the mRNA levels of $W n t 5 a$, which belong to the non-classical Wnt signaling pathway, increased to 4.46, 7.74 and 5.01 times on the 7th, 14th and 21st days of differentiation, respectively (all $p<0.01$ ) (Figure 5B). After adding GSK-3 inhibitors, the mRNA levels of $W n t 5 a$ decreased significantly (Figure 5B). 
A

$(100 \times)$
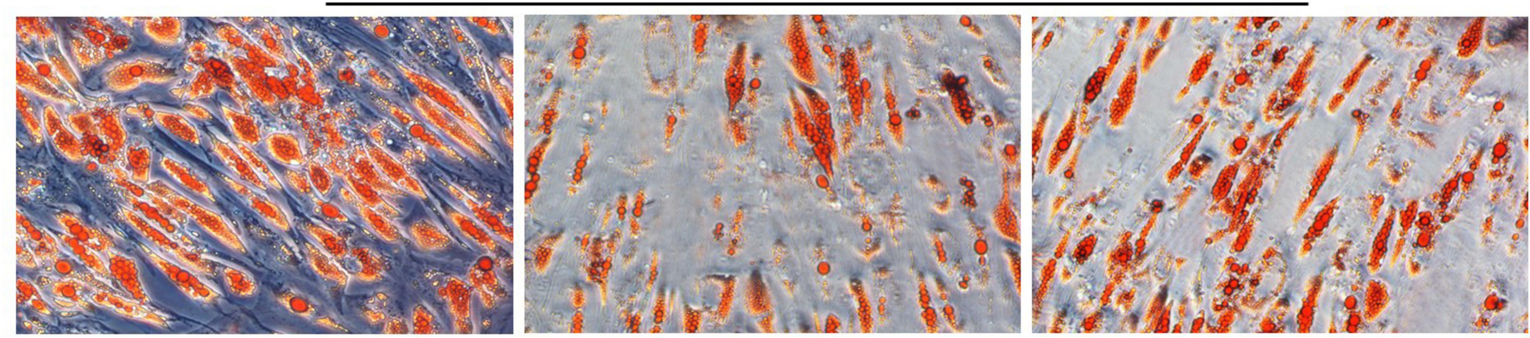

LiCl

SB216763

B

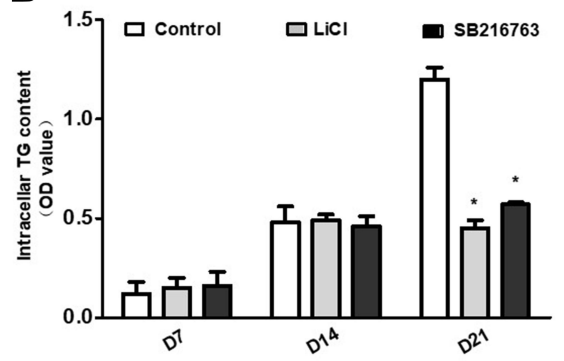

C

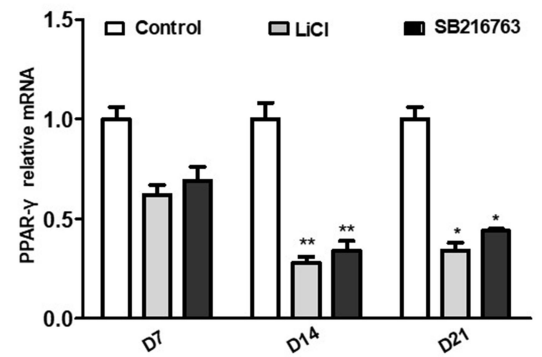

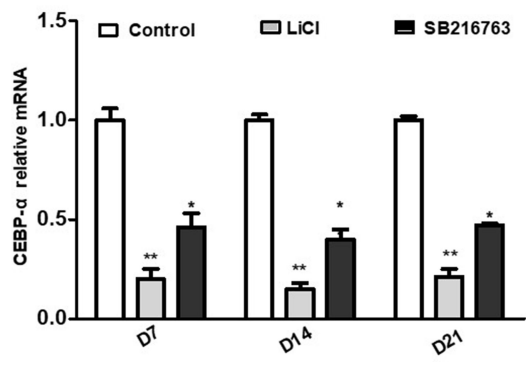

Figure 4 Effects of GSK-3 inhibitors on adipogenesis differentiation. (A) the oil red O staining comparing the effect of LiCl and SB2I6763 on adipogenesis differentiation. (B) the OD value of intracellular TG content after intervening with $\mathrm{LiCl}$ and SB216763 for 7, 14 and 21 days. (C) Changes of PPAR- $\gamma$ and C/EBP- $\alpha$ mRNA levels after intervening with $\mathrm{LiCl}$ and $\mathrm{SB} 216763$ for 7,14 and 21 days $(* \mathrm{p}<0.05, * * \mathrm{p}<0.01)$.

The mRNA levels of Wnt5a in $\mathrm{LiCl}$ group decreased to 0.33 , 0.40 and 0.30 times on the 7 th, 14 th and 21 st days of differentiation, respectively (all $p<0.05$ ) (Figure 5B). While the mRNA levels of $W n t 5 a$ in SB-216763 group decreased to $0.63,0.47$ and 0.49 times on the 7 th, 14 th and 21 st days of differentiation, respectively ( $p$ values were $0.57,0.45$ and 0.48 , respectively) (Figure 5B).

The effects of GSK-3 inhibitors on the expression of GSK- $3 \alpha / \beta$ mRNA and protein were different. At mRNA level, GSK-3 $\alpha$ was down-regulated to 0.41 and 0.40 times, respectively (all $p<0.05$ ), but there was no significant change about $G S K-3 \beta$ on the 7 th day. GSK-3 $\alpha$ was downregulated to 0.34 and 0.36 times, respectively (all $p<0.01$ ). And $G S K-3 \beta$ in $\mathrm{LiCl}$ group increased to 2.18 times $(p<0.01)$, but it showed no significant change in SB216763 group on the 14th day. On the 21 st day, $G S K-3 \alpha$ was down-regulated to 0.27 and 0.38 times, respectively (all $p<0.01)$. And $G S K-3 \beta$ in $\mathrm{LiCl}$ group increased to 2.08 times $(p<0.01)$, but it showed no significant change in SB-216763 group (Figure 5D). In terms of protein levels, GSK-3 $\alpha$ and GSK-3 $\beta$ were significantly up-regulated on the 7 th day, with no significant changes on the 14th and 21 st days. However, both phosphorylated GSK-3 $\alpha$ and GSK-3 $\beta$ were significantly increased (Figure 5E).

\section{Effects of GLP-I Analogue and Insulin on Lipolysis and Lipid Synthesis}

The glycerol content in the supernatant medium during the adipogenesis differentiation of hADSCs was measured as an indicator of lipid decomposition. And the content of triglyceride in cytoplasm was determined as an index of lipid synthesis. The content of intracellular triglyceride increased gradually with the increase of insulin concentration and the prolongation of differentiation time. The difference was statistically significant in the differentiation medium $(10-100 \mathrm{~nm})$ on the 21 st day ( $p$ values were 0.038 and 0.031 , respectively) (Figure 6A). Meanwhile, during the differentiation of hADSCs, the release of glycerol was inversely proportional to the insulin intervention concentration on the 21 st day ( $p$ values were $0.062,0.029,0.005$ and 0.004, respectively) (Figure 6B).

With the increase of liraglutide concentration in the differentiation medium, a slight increase of triglyceride content could be seen, but no statistical significance $(p>0.05)$, indicating that liraglutide had no significant effect on promoting lipid synthesis (Figure 6C). Meanwhile, glycerol content gradually increased with the extension of differentiation time, and the difference was statistically significant 

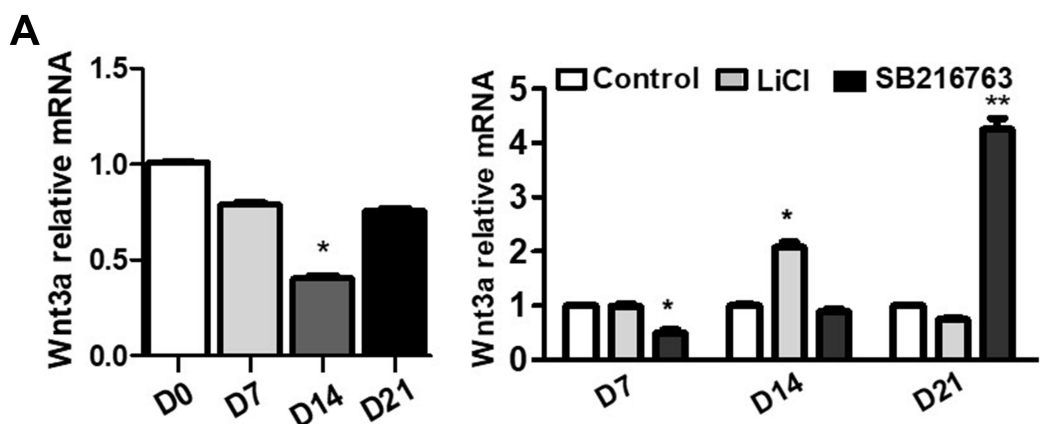

B

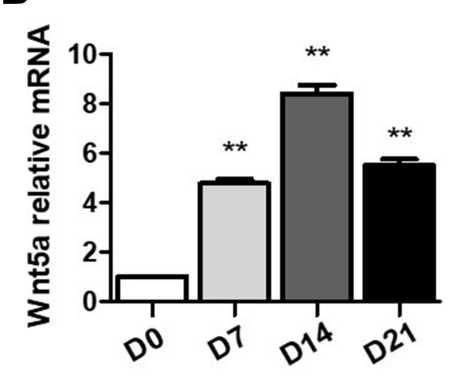

D

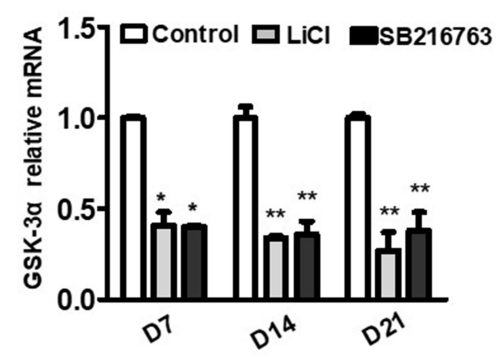

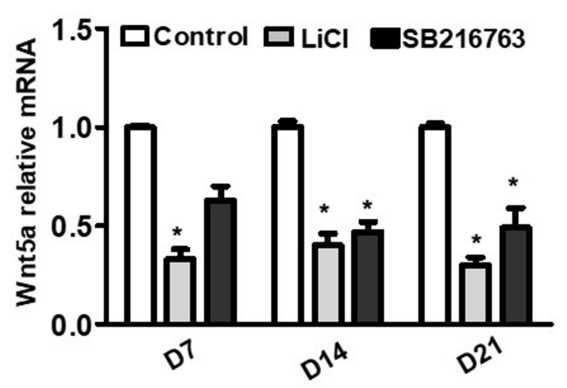

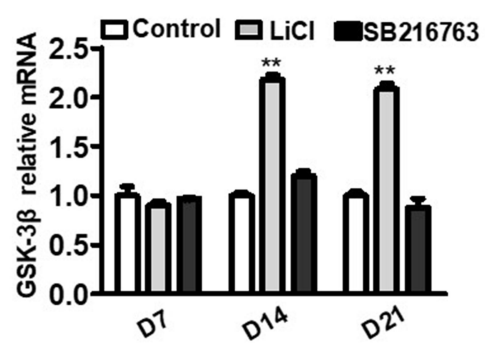

C

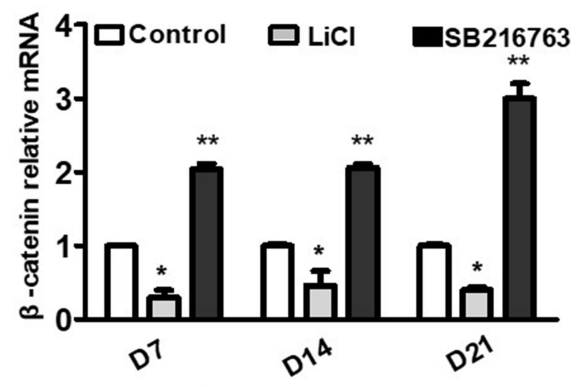

E

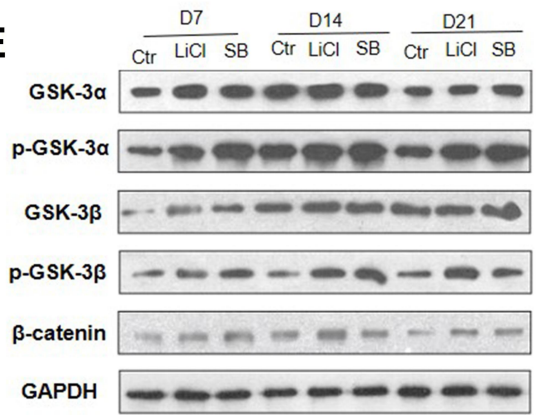

Figure 5 Effects of GSK-3 inhibitors on WNT signaling during adipogenesis differentiation. (A and B) Changes of the Wnt3a and Wnt5a mRNA levels during normal adipogenesis differentiation and after intervening with $\mathrm{LiCl}$ and SB216763 for 7, 14 and 21 days. (C and D) Changes of the $\beta$-catenin, GSK-3 $\alpha$ and GSK-3 $\beta$ mRNA levels during adipogenesis differentiation after intervening with $\mathrm{LiCl}$ and SB2I6763 for 7, 14 and 21 days. (E) Changes of GSK-3 $\alpha$, GSK-3 $\beta$, $\beta$-catenin, $\mathrm{p}-\mathrm{GSK}-3 \alpha$ and $\mathrm{p}-\mathrm{GSK}-3 \beta$ protein levels after intervening with $\mathrm{LiCl}$ and SB216763 for 7,14 and 21 days $\left(* \mathrm{p}<0.05,{ }^{* *} \mathrm{p}<0.01\right.$ ).

$(p<0.05)$. On the 21 st day, the $p$ value was 0.002 when GLP-1 concentration was $100 \mathrm{nM}$, indicating that the decomposition of fat increased significantly with the increase of liraglutide concentrations in the differentiation medium (Figure 6D).

\section{Discussion}

GLP-1 and insulin have opposite effects on body weight, but the specific mechanism remains unknown. Adipocyte, which is the central body of adipose tissue, affects body weight and metabolism of lipids by increasing the number and size. ${ }^{15,17-25}$ Adipocytes are in the process of continuous self-renewal. Old adipocytes are senescent and apoptotic, and new adipocytes, differentiating from ADSCs, are recruited constantly under appropriate conditions. ${ }^{22}$ Recently, some in vitro study showed that GLP-1 promotes the proliferation and/or differentiation of 3T3-L1 preadipocytes (a cell line from mouse) or primary cultured preadipocytes from mouse. ${ }^{26-28}$ Challa et al found that GLP-1 could induce adipocyte formation by promoting preadipocytes proliferation and inhibition of apoptosis, both in vitro and in vivo. ${ }^{29}$ Another study in mice has also revealed that GLP-1 receptor agonist in adipose tissue could promote adipogenesis and reduce adipocyte hypertrophy, which ultimately resulted in markedly reduced visceral fat mass. ${ }^{30}$ Sanz et al found that GLP-1 can significantly downregulate the expression of PPAR- $\gamma, \mathrm{C} / \mathrm{EBP}-\alpha$ and lowdensity lipoprotein (LDL) in the process of lipogenic differentiation of bone marrow mesenchymal stem cells. ${ }^{31}$ Lee et al found that GLP-1 significantly inhibited mRNA levels of adipocyte-specific markers $P P A R-\gamma$, lipoprotein lipase (LPL) and adipocyte protein $2(A P 2) .{ }^{32}$ However, it remains less clear whether GLP-1 and insulin play different roles in 
A

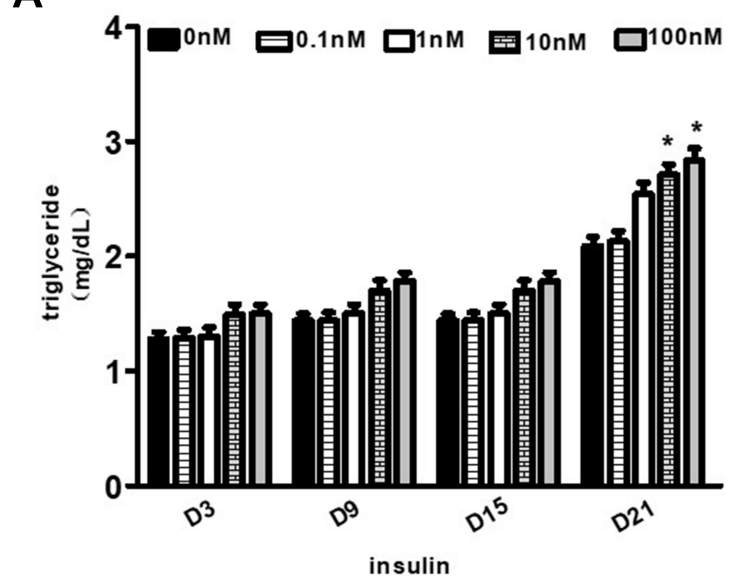

C

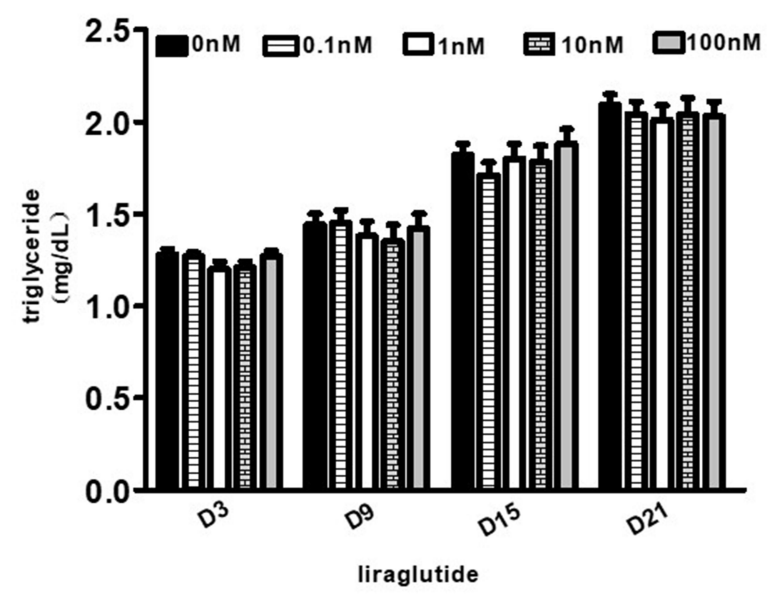

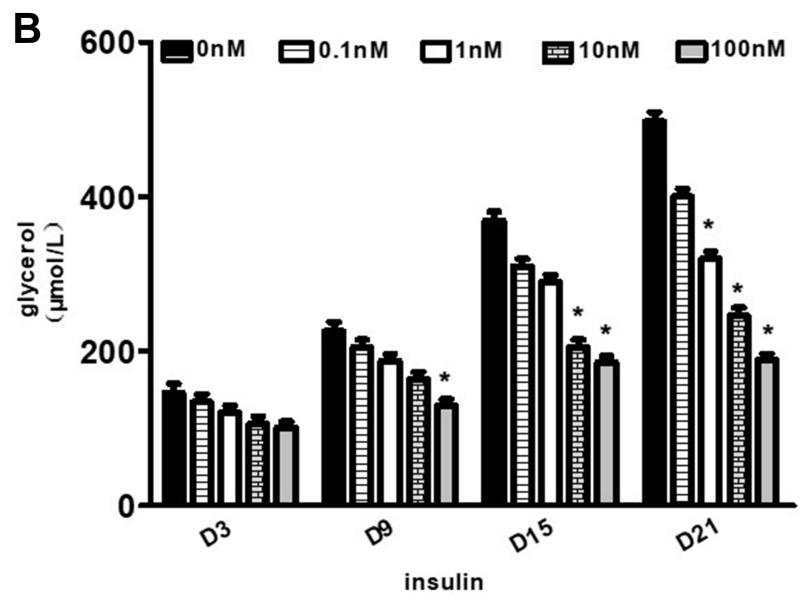

D

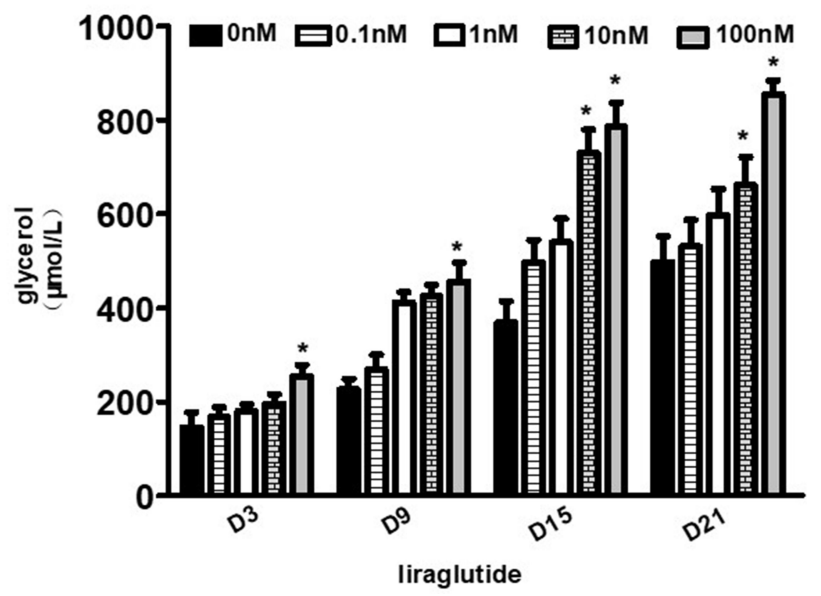

Figure 6 Effects of GLP-I analogue and insulin on lipolysis and lipid synthesis. (A and B) Changes of intracellular triglyceride or glycerol contents with the increase of insulin concentrations and the prolongation of differentiation time. (C and D) Changes of intracellular triglyceride or glycerol content with the increase of liraglutide concentrations and the prolongation of differentiation time $\left({ }^{*} p<0.05\right)$.

the differentiation of adipocytes. In line with previous observations, we confirmed that in hADSCs isolated from subcutaneous adipose that liraglutide inhibited, while insulin promoted the adipogenesis differentiation of ADSCs. Furthermore, we found that GLP-1 could inhibit, while insulin promotes the proliferation of hADSCs, and this effect may be more significant with higher concentrations and longer culture periods.

Our research also found that insulin could inhibit the release of glycerol and promote the production of triglycerides. Yang et al found that the lipid hydrolysis rate of fat cells increased significantly, and the number and size of fat droplets in fat cells decreased significantly with the increase of insulin concentrations (0nM, 200nM, 400nM, $800 \mathrm{nM}$, and $1600 \mathrm{nM}){ }^{33}$ This indicates that different levels of insulin concentrations have different effects on lipid dissociation rate. The higher the concentration, the higher the lipid dissociation rate may be. Clinically, long-term hyperinsulinemia in type 2 diabetes mellitus patients is often accompanied by persistent elevation of free fatty acids (FFAs), ${ }^{34}$ which may further verify that chronic high-dose insulin promotes fat decomposition, and may also explain hyperlipidemia in patients with type 2 diabetes mellitus.

During the past decade, the field involving the link between Wnt/ $\beta$-catenin signaling and metabolic dysfunction is rapidly developing. ${ }^{35}$ The important role of $\mathrm{Wnt} / \beta$-catenin signaling factors has been gradually identified by genetic and biological studies in several metabolic disorders. 5,12,36 $^{\text {Two }}$ subtypes of GSK-3, GSK-3 $\alpha$ and GSK-3 $\beta$, have overlapping but distinct roles in the Wnt signaling pathway. ${ }^{37}$ Our research suggested that liraglutide activated, while insulin inhibited Wnt signaling pathway through phosphorylated GSK-3, thus inhibiting/promoting the proliferation and 
differentiation of hADSCs, respectively. Previous studies had shown that the activity of GSK-3 was high before and during the fusion of 3T3-L1 cells but rapidly declined in the middle and late stages of lipogenic differentiation. ${ }^{38}$ Our results suggested that the expression of GSK-3 was significantly increased during differentiation. The increased multiples of GSK-3 in our RT-PCR results were also very close to those of the increased multiples of GSK-3 measured by ELISA. In contrast, the proteins of GSK-3 $\alpha$ and GSK-3 $\beta$ increased in the early stages, while the proteins of $\mathrm{p}-\mathrm{GSK}-3 \alpha$ and $\mathrm{p}$-GSK-3 $\beta$ up-regulated throughout the differentiation after adding GSK-3 inhibitors in the medium. Our results suggested that GSK-3 inhibitors worked not only by binding to specific sites of GSK-3 but also by affecting the mRNA and protein levels of GSK-3. The early rise of GSK-3 $\alpha$ and GSK-3 $\beta$ may be a transient feedback for regulation the activity of GSK-3. In addition, the opposite changes in mRNA levels of GSK-3 $\alpha$ and GSK-3 $\beta$ may suggest a complementary effect to maintain the function of GSK-3.

Our study also found that GSK-3 inhibitors not only affected the phosphorylation of GSK-3 and $\beta$ catenin but also affected the mRNA and protein levels of GSK-3, including GSK-3 $\alpha$ and GSK-3 $\beta$. In addition, mRNA level of Wnt5a was significantly inhibited, which indicated that non-classical Wnt signaling pathway may be involved in the process of differentiation. Although the protein levels of GSK- $3 \alpha$ and GSK-3 $\beta$ did not change significantly in the middle and late stages of adipogenesis differentiation, $p-G S K-3 \alpha$ and $p-G S K-3 \beta$ increased throughout the differentiation. This may suggest that GSK-3 primarily regulated the classical Wnt signaling pathway through phosphorylation, rather than at transcription and protein levels, and further validated that the effect of GSK-3 inhibitors on hADSCs is primarily through phosphorylation of GSK-3. The primary target of GSK-3 in Wnt signaling pathway was $\beta$-catenin, which was present in both cytoplasm and cell membranes. $\beta$-catenin could regulate Wnt signaling pathway by transporting into the nuclear, while $\beta$-catenin could also be phosphorylated by GSK-3 and then resulted in ubiquitin-dependent degradation. Therefore, GSK-3 inhibition could prevent the phosphorylation and degradation of $\beta$-catenin. From this point of view, cytoplasmic $\beta$-catenin level could be used as a marker for the activity of GSK-3.

Surprisingly, the RT-PCR results showed that $\mathrm{LiCl}$ and SB-216763 caused different changes in the mRNA level of $\beta$-catenin. $\mathrm{LiCl}$ caused the mRNA level of $\beta$-catenin decreased significantly, while SB-216763 increased it.
However, at the protein level, the two inhibitors both increased the protein expression of $\beta$-catenin significantly. This seemingly conflicting result was not unique to our study. Gould et al also found that mice treated with lithium chloride showed a significant decrease in the mRNA level of $\beta$-catenin but a significant increase in protein level. ${ }^{39}$ The increase in protein level of $\beta$-catenin may be due to increased mRNA transcription level or reduced posttranscriptional protein degradation. Our study suggested that the change of the $\beta$-catenin mRNA level were not the main pathway by which GSK-3 played its role. GSK-3 inhibitors may down-regulate Wnt5a by inhibiting nonWnt signaling pathways, which may be a positive regulator of adipogenic differentiation. However, the specific mechanism needs to be further studied.

\section{Strengths and Limitations of the Study}

The present study has several limitations. First, only MTT method was used to evaluate the effects of liraglutide and insulin on hADSCs proliferation. More methods are needed in the future study, such as the Cell Counting Kit. Second, it was not clear in our experiment whether GSK-3 $\alpha$ or GSK-3 $\beta$ was more important because of the lack of specific GSK-3 $\alpha$ and GSK-3 $\beta$ inhibitors. Selective silence or knockout of GSK $-3 \alpha$ or GSK-3 $\beta$ is a better way to confirm the effect of GSK-3. Third, these are in vitro results only. Further investigations are needed to examine the effect in vivo.

Despite these limitations, our study also has notable strengths. Our findings put new insights into the direct effects of GLP-1 and insulin on the adipogenesis of hADSCs. First, our study found that liraglutide promoted fat decomposition, which may be one of the reasons why liraglutide could reduce body mass while controlling blood glucose. In contrast to liraglutide, insulin promoted proliferation of hADSCs and fat synthesis. The discovery provides a direction for the application of GLP-1 in the treatment of obesity and other metabolic diseases. Second, according to the mounting evidences and our recent interesting findings that Wnt signaling was important for obesity development. The study of GSK-3 in ADSCs proliferation and differentiation has promising effect to find new therapeutic targets for treatment of obesity.

\section{Conclusion}

Liraglutide and insulin have contrary effects on the proliferation and adipogenesis via Wnt pathway in primary cultured 
hADSCs. Those effects could partly explain the distinct roles of GLP-1 and insulin on weight gain and insulin resistance.

\section{Funding}

This study was supported by the National Natural Science Foundation of China (Grant 81670815), Guangdong Basic and Applied Basic Research Foundation (Grant 2020A1515010124), Special fund for innovation strategy of science and technology plan of Guangdong province (2019A030317011) and the Major Project for Young Teachers of Sun Yat-sen University (17ykzd23).

\section{Disclosure}

The authors report no conflicts of interest in this work.

\section{References}

1. Hammarstedt A, Gogg S, Hedjazifar S, et al. Impaired adipogenesis and dysfunctional adipose tissue in human hypertrophic obesity. Physio Rev. 2018;98:1911-1941.

2. Grant RW, Dixit VD. Adipose tissue as an immunological organ. Obesity. 2015;23:512-518. doi:10.1002/oby.21003

3. Cai X, Hayashi S, Fang C, et al. Pu'erh tea extract-mediated protection against hepatosteatosis and insulin resistance in mice with dietinduced obesity is associated with the induction of de novo lipogenesis in visceral adipose tissue. $J$ Gastroenterol. 2017;52:1240-1251. doi:10.1007/s00535-017-1332-3

4. Arner E, Westermark PO, Spalding KL, et al. Adipocyte turnover: relevance to human adipose tissue morphology. Diabetes. 2010;59:105-109. doi:10.2337/db09-0942

5. Laudes M. Role of WNT signalling in the determination of human mesenchymal stem cells into preadipocytes. $J$ Mol Endocrinol. 2011;46:R65-72. doi:10.1530/JME-10-0169

6. Flier JS. Starvation in the midst of plenty: reflections on the history and biology of insulin and leptin. Endocr Rev. 2019;40:1-16. doi:10.1210/er.2018-00179

7. Hall KD, Guyenet SJ, Leibel RL. The carbohydrate-insulin model of obesity is difficult to reconcile with current evidence. JAMA Inter Med. 2018;178:1103-1105. doi:10.1001/jamainternmed.2018.2920

8. Brown E, Cuthbertson DJ, Wilding JP. Newer GLP-1 receptor agonists and obesity-diabetes. Peptides. 2018;100:61-67. doi:10.1016/j. peptides.2017.12.009

9. Aroda VR. A review of GLP-1 receptor agonists: evolution and advancement, through the lens of randomised controlled trials. Diabetes Obes Metab. 2018;20:22-33. doi:10.1111/dom.13162

10. Muller TD, Finan B, Bloom SR, et al. Glucagon-like peptide 1 (GLP-1). Mol Metab. 2019;30:72-130. doi:10.1016/j.molmet.2019. 09.010

11. Aamir K, Khan HU, Sethi G, et al. Wnt signaling mediates TLR pathway and promote unrestrained adipogenesis and metaflammation: therapeutic targets for obesity and type 2 diabetes. Pharmacol Res. 2020;152:104602. doi:10.1016/j.phrs.2019.104602

12. Chen N, Wang J-Q. Wnt/B-catenin signaling and obesity. Front Physiol. 2018;9:792. doi:10.3389/fphys.2018.00792

13. Lu H-Y, Li X-F, Mu P-W, et al. Dickkopf-1 promotes the differentiation and adipocytokines secretion via canonical Wnt signaling pathway in primary cultured human preadipocytes. Obes Res Clin Pract. 2016;10:454-464. doi:10.1016/j.orcp.2015.08.016

14. Carswell KA, Lee MJ, Fried SK. Culture of isolated human adipocytes and isolated adipose tissue. Methods Mol Biol. 2012;806:203-214.
15. Xiao-ying H, Guan H-Y, Liang W-W, et al. Exendin-4 modifies adipogenesis of human adipose-derived stromal cells isolated from omentum through multiple mechanisms. Int $J$ Obes. 2018;42 (5):1051-1061. doi:10.1038/s41366-018-0024-2

16. Hong-yun L, Gao Z-G, Zhao Z-Y, et al. Transient hypoxia reprograms differentiating adipocytes for enhanced insulin sensitivity and triglyceride accumulation. Int J Obes. 2016;40:121-128. doi:10.1038/ ijo.2015.137

17. Su X, Peng D. The exchangeable apolipoproteins in lipid metabolism and obesity. Clin Chim Acta. 2020;503:128-135. doi:10.1016/j. cca.2020.01.015

18. Andersen A, Lund A, Knop FK, et al. Glucagon-like peptide 1 in health and disease. Nat Rev Endocrinol. 2018;14:390-403. doi:10.1038/s41574-018-0016-2

19. Sun K, Kusminski CM, Scherer PE. Adipose tissue remodeling and obesity. J Clin Invest. 2011;121:2094-2101. doi:10.1172/JCI45887

20. Salans LB, Cushman SW, Weismann RE. Studies of human adipose tissue. Adipose cell size and number in nonobese and obese patients. J Clin Invest. 1973;52(4):929-941. doi:10.1172/JCI107258

21. Hirsch J, Batchelor B. Adipose tissue cellularity in human obesity. Clin Endocrinol Metab. 1976;5:299-311. doi:10.1016/S0300-595X (76)80023-0

22. Spalding KL, Arner E, Westermark PO, et al. Dynamics of fat cell turnover in humans. Nature. 2008;453:783-787. doi:10.1038/nature06902

23. Arner P, Andersson DP, Thorne A, et al. Variations in the size of the major omentum are primarily determined by fat cell number. J Clin Endocrinol Metab. 2013;98:E897-901. doi:10.1210/jc.2012-4106

24. Wang Y, Rimm EB, Stampfer MJ, et al. Comparison of abdominal adiposity and overall obesity in predicting risk of type 2 diabetes among men. Am J Clin Nutr. 2005;81:555-563. doi:10.1093/ajcn/81.3.555

25. Phillips LK, Prins JB. The link between abdominal obesity and the metabolic syndrome. Curr Hypertens Rep. 2008;10:156-164. doi:10.1007/s11906-008-0029-7

26. Yang J, Ren J, Song J, et al. Glucagon-like peptide 1 regulates adipogenesis in 3T3-L1 preadipocytes. Int $J$ Mol Med. 2013;31:1429-1435. doi:10.3892/ijmm.2013.1350

27. Chen J, Zhao H, Ma X, et al. GLP-1/GLP-1R signaling in regulation of adipocyte differentiation and lipogenesis. Cell Physiol Biochem. 2017;42(3):1165-1176. doi:10.1159/000478872

28. Zhang Y, Chen S, Liu B, et al. Exendin-4 promotes proliferation of adipose-derived stem cells through ERK and JNK signaling pathways. Vitr Cell Dev Biol - Anim. 2016;52:598-606. doi:10.1007/s11626-016-0003-7

29. Challa TD, Beaton N, Arnold M, et al. Regulation of adipocyte formation by GLP-1/GLP-1R signaling. $J$ Biol Chem. 2012;287:6421-6430. doi:10.1074/jbc.M111.310342

30. He M, Su H, Gao W, et al. Reversal of obesity and insulin resistance by a non-peptidic glucagon-like peptide-1 receptor agonist in diet-induced obese mice. PLoS One. 2010;5:e14205. doi:10.1371/ journal.pone. 0014205

31. Sanz C, Vazquez P, Blazquez C, et al. Signaling and biological effects of glucagon-like peptide 1 on the differentiation of mesenchymal stem cells from human bone marrow. Am J Physiol Endocrinol Metab. 2010;298:E634-643. doi:10.1152/ajpendo.00460.2009

32. Lee HM, Joo BS, Lee CH, et al. Effect of Glucagon-like Peptide-1 on the differentiation of adipose-derived stem cells into osteoblasts and adipocytes. J Menopausal Med. 2015;21:93-103. doi:10.6118/jmm.2015.21.2.93

33. Yang YQ, Ju DP, Zhang MT, et al. Chronic high doses of insulin stimulates the breakdown of pig fat cells. Journal Biol Eng. 2009;1:16-22.

34. Zhang J, Hupfeld CJ, Taylor SS, et al. Insulin disrupts beta-adrenergic signalling to protein kinase A in adipocytes. Nature. 2005;437:569-573. doi:10.1038/nature04140

35. Faulds KJ, Egelston JN, Sedivy LJ, et al. Glycogen synthase kinase-3 (GSK-3) activity regulates mRNA methylation in mouse embryonic stem cells. J Biol Chem. 2018;293:10731-10743. doi:10.1074/jbc. RA117.001298 
36. Kanazawa A, Tsukada S, Sekine A, et al. Association of the gene encoding wingless-type mammary tumor virus integration-site family member 5B (WNT5B) with type 2 diabetes. Am J Hum Genet. 2004;75:832-843. doi:10.1086/425340

37. Liu X, Klein PS. Glycogen synthase kinase-3 and alternative splicing. Wiley Interdiscip Rev RNA. 2018;9:e1501. doi:10.1002/wrna.1501

38. Benjamin WB, Pentyala SN, Woodgett JR, et al. ATP citrate-lyase and glycogen synthase kinase-3 beta in 3T3-L1 cells during differentiation into adipocytes. Biochem J. 1994;300:477-482. doi:10.1042/bj3000477
39. Gould TD, Chen G, Manji HK. In vivo evidence in the brain for lithium inhibition of glycogen synthase kinase-3. Neuropsychopharmacology. 2004;29:32-38. doi:10.1038/sj.npp.1300283

Diabetes, Metabolic Syndrome and Obesity: Targets and Therapy

\section{Publish your work in this journal}

Diabetes, Metabolic Syndrome and Obesity: Targets and Therapy is an international, peer-reviewed open-access journal committed to the rapid publication of the latest laboratory and clinical findings in the fields of diabetes, metabolic syndrome and obesity research. Original research, review, case reports, hypothesis formation, expert opinion and commentaries are all considered for publication. The manuscript management system is completely online and includes a very quick and fair peer-review system, which is all easy to use. Visit http://www.dovepress.com/testimonials.php to read real quotes from published authors. 